\title{
Gastrointestinal nematode infection in beef cattle raised in silvopastoral and conventional systems in São Paulo state, Brazil
}

\author{
M. C. S. Oliveira $\cdot$ M. L. F. Nicodemo $\cdot$ J. R. M. Pezzopane $\cdot$ \\ M. R. Gusmão • A. C. S. Chagas • R. Giglioti • T. B. Bilhassi • \\ C. H. Santana • T. C. Gonçalves • M. D. Rabelo • T. A. Néo
}

Received: 25 September 2015/Accepted: 22 April 2016/Published online: 30 April 2016

(C) Springer Science+Business Media Dordrecht 2016

\begin{abstract}
The use of silvopastoral systems (SPS) can be a good alternative to reduce the environmental impacts of livestock breeding in Brazil. Despite the advantages offered by public policies, many producers hesitate to use this system. One of the reasons is the lack of information on health and productivity of cattle raised under these conditions. The experiment reported here was designed to compare the behavior of infection by gastrointestinal nematodes and weight gain of beef cattle raised in a SPS and a conventional pasture system. We monitored the number of eggs per gram of feces, the prevalent nematode genus, data on climate, forage availability, weight gain and packed cell volume (PCV) of the animals bred in the two systems. The infection by nematodes was significantly
\end{abstract}

M. C. S. Oliveira · M. L. F. Nicodemo $(\bowtie)$.

J. R. M. Pezzopane - M. R. Gusmão ·

A. C. S. Chagas - M. D. Rabelo

Embrapa Pecuária Sudeste, Rodovia Washington,

Luiz km 234, São Carlos, SP, Brazil

e-mail: marialuiza.nicodemo@embrapa.br

R. Giglioti - T. B. Bilhassi - C. H. Santana

Departamento de Zootecnia, UNESP, Jaboticabal, SP, Brazil

T. C. Gonçalves

UNICEP, São Carlos, SP, Brazil

T. A. Néo

Universidade Federal de São Carlos, São Carlos, SP, Brazil higher in the cattle raised in the SPS $(\mathrm{p}<0.05)$. The coprocultures revealed the presence of nematodes of the genera Haemonchus, Cooperia, Oesophagostomum and Trichostrongylus, in both systems, but the mean infestation rates of Haemonchus and Cooperia were higher in the SPS $(\mathrm{p}<0.05)$. The average of PCV values did not differ between the cattle in the two systems. The individual weight gain and stocking rate in the period did not vary between the systems $(p>0.05)$. Despite the higher prevalence of nematodes in the SPS, no negative impact was detected on the animals' weight gain and health. The results of this experiment indicate that under the conditions studied, there is no need to alter the parasite management to assure good productive performance of cattle.

Keywords Nematodes $\cdot$ Cattle $\cdot$ Weight gain · Silvopastoral systems

\section{Introduction}

Stockbreeding is an important economic activity in Brazil. According to the most recent rural census (IBGE 2006), it occupies approximately 158 million hectares, far more area than the 59.8 million hectares used to grow crops. Between 1990 and 2008, production of beef rose from 4.1 to over 9.3 million (metric) tons, a much more pronounced expansion than the country's population and consumption. This 
combination of factors allowed Brazil to become one of the world's leading exporters of beef (Schlesinger 2010). The large expansion of stockbreeding, however, has raised concerns among some sectors of society, due mainly to the advance of cattle raising into the Amazon region and the aggravation of the greenhouse effect the activity can cause. It is believed that the adoption of silvopastoral systems (SPS), which combine pasture to graze cattle with trees, can be a good alternative to minimize the negative effects of stockbreeding on the environment. Besides this, ranchers can benefit from government incentives to convert part of their land from conventional pasture systems (CPS) into arborized systems. However, despite these advantages, many ranchers are reluctant to make the switch, largely due to the lack of information on the health and productivity of animals raised under SPS in Brazil's tropical conditions.

Infections by gastrointestinal nematodes can drastically reduce the productivity of cattle under extensive grazing practices (Corwin 1997; Araujo and Lima 2005; Stromberg and Gasbarre 2006; Stromberg et al. 2012). Environmental factors, mainly temperature and air humidity/soil moisture, have a strong influence on the development, survival and distribution of nematodes in pastures (Stromberg 1997). SPS typically have lower levels of evapotranspiration, solar radiation and wind speed and more stable temperature and soil moisture than CPS (Garcia and Couto 1991; Souza et al. 2010). Apart from shade, the higher quantity and variety of plants in SPS can alter biodiversity, influencing the survival of the free-living forms of parasites (Martinez and Merino 2011). Arborization of pastures can also affect the supply and quality of forage grasses, affecting both the health of herds and of the gastrointestinal parasites that depend on the nutritional state of cattle for their development cycle (Parkins and Holmes 1989; Araujo and Lima 2005; Stromberg and Gasbarre 2006).

The behavior of infections caused by gastrointestinal parasites in cattle raised in SPS has not been systematically studied, and the few published articles contain conflicting results. Soca et al. (2007) investigated young cattle in Cuba and found significantly lower eggs per gram (EPG) values in animals bred in SPS compared to those raised in a system without trees. In contrast, Mendonça et al. (2014), in a study in the state of Minas Gerais in southeastern Brazil, did not find significant differences in EPG and weight gain in young cattle kept in the two systems. Hence, there is a need to obtain more data to support the adoption of SPS by Brazilian stockbreeders. This study was carried out to compare the pattern of infection by gastrointestinal nematodes in beef cattle raised in SPS and CPS, to indicate whether or not there is a need to change sanitary management practices. For this purpose, we simultaneously monitored data on microclimate, forage availability and animal weight gain along with collection of feces to assess the parasite burdens in the two production systems.

\section{Materials and methods}

Experimental area and animals

The study was carried out at the experimental ranch of Embrapa Pecuária Sudeste (Embrapa Southeast Livestock Research Unit), located in São Carlos, São Paulo state $\left(22^{\circ} 01^{\prime} \mathrm{S}\right.$ and $\left.47^{\circ} 53^{\prime} \mathrm{W}\right)$. The region's climate is classified as Cwa (Köppen), with two well-defined seasons: dry from April to September and rainy from October to March. The average annual temperature is $21.2{ }^{\circ} \mathrm{C}$ and the average yearly air humidity is $75.6 \%$. The terrain in the area is gently rolling, with slopes between 3 and $5 \%$, and average altitude of $860 \mathrm{~m}$. The SPS was established in December 2007 by planting 4519 tree seedlings in a pasture area containing Urochloa decumbens (Stapf.) Webster (syn. Brachiaria decumbens) in a dark red latosol (Embrapa 2006) with medium texture $(699 \mathrm{~g} / \mathrm{kg}$ of sand, $232 \mathrm{~g} / \mathrm{kg}$ of clay and $69 \mathrm{~g} / \mathrm{kg}$ of silt). The trees were planted in bands of three rows spaced $17 \mathrm{~m}$ apart, following the contour of the terrain and with distances between trees in the band of $2.5 \times 2.5 \mathrm{~m}^{2}$, resulting in 600 trees/ha (Fig. 1).

The following tree species were planted in the central row of the band: angico-branco (Anadenanthera colubrina Vell.); canafístula (Peltophorum dubium Spreng.); ipê-felpudo (Zeyheria tuberculosa Vell.); jequitibá-branco (Cariniana estrellensis Raddi) and pau-jacaré (Piptadenia gonoacantha (Mart.) J. F. Macbr.). To ameliorate bole conformation of these species, two marginal rows were planted of mutambo (Guazuma ulmifolia Lam.) and capixingui (Croton floribundus Spreng). The pasture was divided into six paddocks of 0.5 ha, with two area repetitions. The bands with trees remained protected from cattle by an 


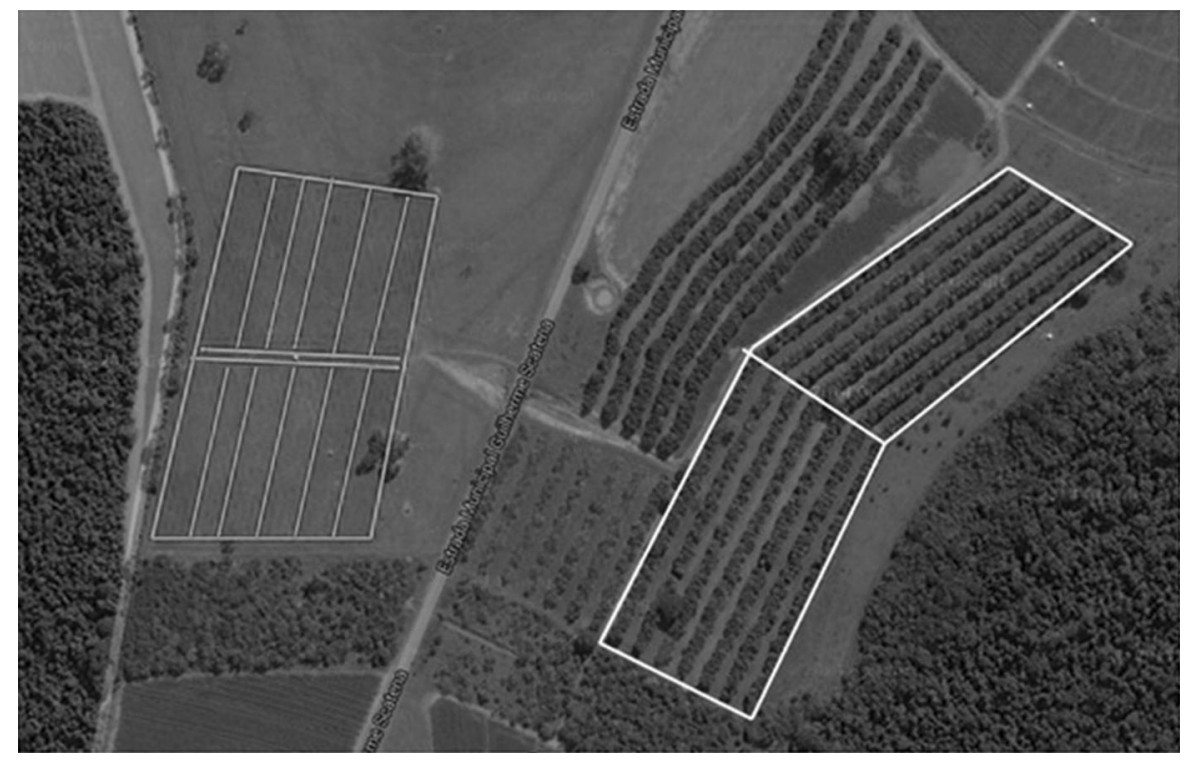

Fig. 1 Representative sketch of CPS (left) and SPS (right), at the experimental farm of Embrapa, São Carlos, SP, Brazil

electric fence during the entire experimental period, so that the grazing area in each paddock was 0.41 ha. The CPS was composed of six paddocks of $U$. decumbens, each with 0.5 ha, with two area repetitions. The herds in the two systems were composed of Canchim cattle (5/8 Charolais $+3 / 8$ Zebu). All the animals had been weaned at approximately 8 months and were identified by numbered ear tags, vaccinated against foot-andmouth disease and clostridiosis and treated with an acaricide (Colosso, Ouro Fino) and an anthelmintic (Ricobendazole, Ouro Fino) before being placed in the paddocks. During the experimental period, the animals were not treated with anthelmintics and had access to mineral supplement and water ad libitum. During the dry season, they received a protein-enriched mineral ad libitum and in the winter of 2014, the animals in the SPS received supplementary sugarcane-based fodder.

Rotated grazing was adopted, according to the method described by Euclides and Euclides Filho (1998), and the pastures were fertilized annually at the start of the rainy season to maintain grass production. The grazing period in each paddock was 7 days, with 35 days of rest, for a cycle of 42 days. At the end of each cycle, the animals were weighed (after fasting for $16 \mathrm{~h}$ ) and returned to the original paddock. The number of animals in each production system depended on the amount of forage available, according to the grass height, for adjustment of the stocking rate. Additional animals were placed in and removed from each paddock according to the amount of forage available, so as to keep the grass height in the range of $10-15 \mathrm{~cm}$ after grazing. The number of days the additional animals remained in the pastures was considered to calculate the productivity by area and stocking rate. Samples were obtained from the 24 animals (testers, 12 from each system) at 42-day intervals, corresponding to the grazing cycle. The experiment was approved by the Animal Research Ethics Committee of Embrapa Pecuária Sudeste (CEUA/CPPSE, Protocol No. 04/2013). The animals were monitored on 15 occasions after being allocated to the paddocks, the first time on August 1, 2013, after the first grazing cycle, and the last on March 12, 2015.

\section{Environmental factors}

Meteorological data were obtained from the Embrapa Pecuária Sudeste weather station, to characterize the climate during the experimental period. The climatological water balance was calculated from the temperature and rainfall data according to the method of Thornthwaite and Mather (1955).

To investigate the influence of environmental factors, data were obtained on air and soil temperature 
(maximum, minimum and average values in ${ }^{\circ} \mathrm{C}$ ), overall mean solar radiation $\left(\mathrm{MJ} / \mathrm{m}^{2} /\right.$ day), and wind speed $(\mathrm{m} / \mathrm{s})$ in the two systems. The observations were carried out continuously, at four points between the two bands of trees in the SPS and at one point in the CPS, for calculation of the monthly averages for the two systems.

The soil moisture was determined with a Diviner ${ }^{\circledR}$ capacitance sensor, measured weekly in four repetitions down to a depth of $1 \mathrm{~m}$, but only the soil moisture data to $10 \mathrm{~cm}$ depth were used. In the SPS, the access tubes for determination of soil moisture were installed at four points between the two bands of trees, to obtain the average values for the system.

\section{Parasitological analysis}

The fecal samples were collected directly from the rectum with plastic sacks and were taken to the laboratory in polystyrene foam ice chests. The technique of Gordon and Whitlock, as modified by Ueno and Gonçalves (1989), was used to calculate the number of EPG of feces in the samples. At the same time, coprocultures were prepared according to the method described by Roberts and O'Sullivan (1950), to identify the prevalent nematode genera in the two production systems.

\section{Availability of pasture}

The supply of dry green matter was estimated by harvesting grass samples in four paddocks at random from each treatment, in each season of the year, just before entrance of the animals. Representative samples from the two systems, obtained at random (in the CPS) or along five transects (SPS), were cut at ground level. The transects between the two bands of trees were sampled at three points: $2 \mathrm{~m}$ from the outside row of trees, in the middle of the paddock, and at an intermediate point. Subsamples were dried in a forced-air oven at $60{ }^{\circ} \mathrm{C}$ for $72 \mathrm{~h}$ to calculate the total available dry matter ( $\mathrm{kg}$ of dry matter/ha). Other subsamples were used for morphological separation into green leaves, green stems and dead material. The material was dried in an oven and the percentage of each component in the forage supplied was calculated. The supply of dry green matter $(\mathrm{kg} / \mathrm{ha})$ was calculated as total dry matter $\times(100$ - $(\%$ of dead matter $)) / 100$.
Weight gain, comfort and health of the animals

At the end of each grazing cycle, the animals were weighed to calculate the individual weight gain. The number and weight of the animals kept in the paddocks were monitored to calculate the stocking rate, expressed as animal units per hectare (AU/ha). To monitor the animals' health, venous blood samples are taken with a vacuum system for determination of the packed cell volume (PCV) by the microhematocrit technique (Jain 1993).

The climate data were used to determine the temperature and humidity index (THI), used as an indicator of thermal comfort, calculated according to the following formula (Takahashi et al. 2009):

$\mathrm{THI}=\mathrm{T}+0.36 \times \mathrm{Tdp}+41.5$,

where $\mathrm{T}=$ air temperature $\left({ }^{\circ} \mathrm{C}\right)$ and $\mathrm{Tdp}=$ dew point temperature $\left({ }^{\circ} \mathrm{C}\right)$.

The dew point temperature $\left(\mathrm{Tdp},{ }^{\circ} \mathrm{C}\right)$ was calculated from the air temperature $\mathrm{T}\left({ }^{\circ} \mathrm{C}\right)$ and relative air humidity (RH, \%) according to the formula below (Aguilar et al. 1986):

$$
\begin{aligned}
T d p= & T-(14.55+0.114 \times T) \\
& \times[(1-(0.01 \times R H)]-\{(2.5+0.007 \times T) \\
& \times[1-(0.01 \times R H)]\}^{3}-(15.9+0.117 \times T) \\
& \times[1-(0.01 \times R H)]^{14}
\end{aligned}
$$

According to the THI, the environment can be classified as follows: $\mathrm{THI}=70$-normal condition; $70<$ THI $<78$ - critical; $79<$ THI $<83$-danger; THI $>83$-emergency. THI was calculated for the experimental period, using daily maximal temperature and lowest RH values in order to identify extreme differences among systems, normally found around midday.

\section{Statistical analysis}

For the statistical analysis, the data on EPG and the counts of helminth species (HS) were transformed into $\log 10(n+1)$ to approximate the distribution to the normal distribution. The PCV data were analyzed considering repeated measures, using the MIXED procedure of the SAS program (2002/2003), employing a model including as fixed effects the system, sample collection (month/year) and their interactions, besides 
the random effects animal and residual. A compound symmetry structure was used for the covariance matrix. For the HS data, the same procedure mentioned above was used, but the nematode species variable was included as a fixed effect. The climate data were analyzed using the GLM program (SAS 2002/2003). The animal weight and THI data were analyzed for normality (Kolmogorov and Shapiro-Wilks tests), with the aid of the Infostat software (Di Rienzo et al. 2011). Depending on the results of these tests, the data were submitted to analysis of variance, considering the system and date/season, as well as their interactions, by means of the Tukey test and Kruskal-Wallis test, in both cases at $5 \%$ probability.

\section{Results}

The water balance data at the Embrapa Pecuária Sudeste experimental ranch are represented in Fig. 2. After a mild dry period in the winter of 2013, the rain returned at the start of September, causing an increase in the soil moisture, and water surpluses were observed in October and November. A new water deficiency period started in December 2013, and with the exception of April and May 2014, there were low water availability levels in all months that year, with deficiencies ranging from moderate to severe. Between January and October 2014, the water deficiency was $225 \mathrm{~mm}$, with total rainfall of $550 \mathrm{~mm}$. The rainfall only returned to normal in November 2014, generating the first water surpluses of the year in that month and December. Rainfall in
2014 was below the historic averages for the region. More water was available at the start of 2015 .

Table 1 shows the means of the meteorological metrics in the CPS and SPS during the study period. The overall solar radiation values (mean followed by standard error) were $10.83 \pm 0.17$ and $17.35 \pm$ $0.17 \mathrm{MJ} / \mathrm{m}^{2} /$ day, for the SPS and CPS, respectively. The solar radiation was lower in the SPS in all the evaluations $(p<0.05)$, and the greatest attenuations were observed in April 2014 and March 2015, with values of $50 \%$, probably due to the solar declination and more plentiful leaves on the trees in this period. Significant differences $(p<0.05)$ were observed for wind speed in the two systems, with figures of $1.36 \pm 0.02 \mathrm{~m} / \mathrm{s}$ for the CPS and $0.64 \pm 0.02 \mathrm{~m} / \mathrm{s}$ for the SPS. These values represent reductions of 34.8 to $65.1 \%$ in the SPS in relation to the CPS. Regarding soil and air temperature, the averages also differed significantly ( $\mathrm{p}<0.05$ ) between the two systems, with values of $22.47 \pm 0.05$ (CPS), $22.22 \pm 0.05$ (SPS) and $21.42 \pm 0.07$ (CPS) and $21.19 \pm 0.07$ (SPS), respectively.

The quantities of water stored in the topmost soil layer $(0-10 \mathrm{~cm})$ in the pastures of the two experimental areas did not significantly differ $(0.21 \pm 0.03 \mathrm{~mm})$. The average quantity of water was only lower under the trees in the SPS $(0.20 \pm 0.04 \mathrm{~mm})$.

Parasitological analysis

The animals in the SPS had higher average EPG throughout most of the experiment (Fig. 3). The

Fig. 2 Water balance observed between July 2013 and March 2015 at the experimental farm of Embrapa, São Carlos, SP, Brazil

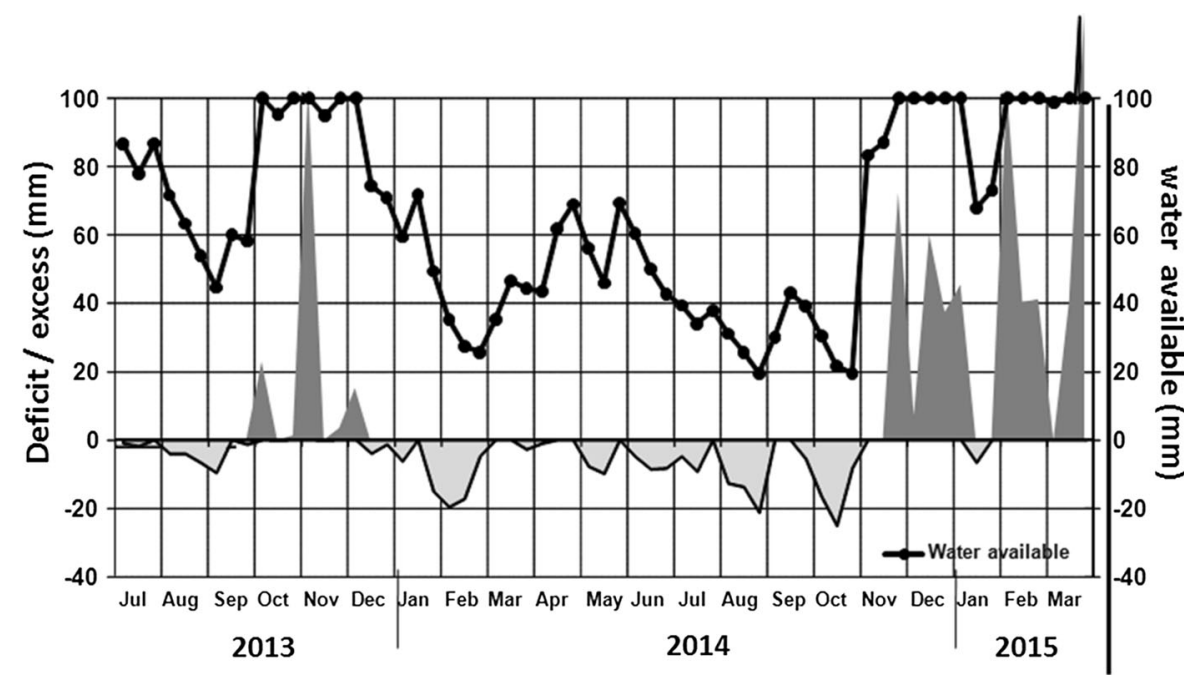




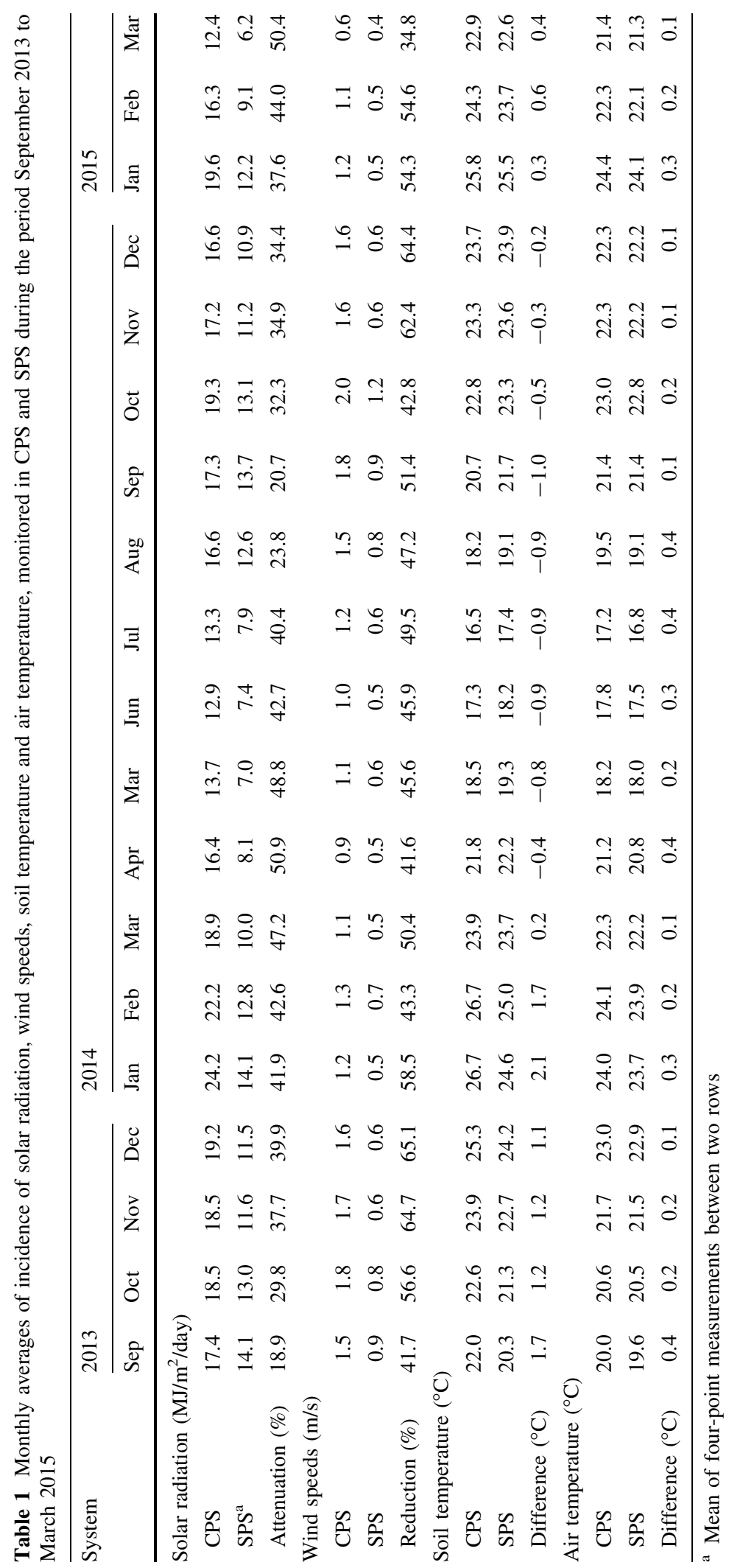


values were near each other between the two systems only in April, August and December 2014 and March 2015. The statistical analysis of the data indicated a significant difference for the effect of the collection month and system $(\mathrm{p}<0.05)$. The log-transformed mean EPG values were $1.65 \pm 0.14$ and $1.15 \pm 0.20$ for the SPS and CPS, respectively. The parasite genera identified in the coprocultures were Haemonchus, Cooperia, Oesophagostomum and Trichostrongylus, in both systems (Fig. 4). There was a significant effect $(p<0.05)$ of the interaction between system and nematode genus, where the average numbers of Haemonchus and Cooperia larvae were greater in the SPS. The means and standard errors of the number of larva found in the animals in the SPS and CPS were, respectively: Haemonchus $-1.47 \pm 0.10$ and $0.94 \pm$ 0.15 ; Cooperia $-0.60 \pm 0.10$ and $0.22 \pm 0.15$; Trichostrongylus $-0.63 \pm 0.10$ and $0.42 \pm 0.15$; and Oesophagostomum $-0.76 \pm 0.10$ and $0.36 \pm 0.15$.

Health, comfort and weight gain

During the entire experiment the animals showed little variation in $\mathrm{PCV}$ - the means did not differ statistically between the two systems: $35.19 \pm 0.86$ and $36.73 \pm 0.91 \%$ (mean \pm standard error) for the SPS and CPS, respectively.

THI values varied across the year, with lower values in winter $(72 \pm 0.2$, mean \pm standard error) and higher values in summer $(78 \pm 0.1 ; \mathrm{p}<0.05)$. Mean THI values were higher for CPS compared to SPS in every season $(\mathrm{p}<0.05)$ : winter $=73 \pm 0.3$ versus $72 \pm 0.3$; autumn $=75 \pm 0.2$ versus $73 \pm$ 0.2 ; spring $=77 \pm 0.3$ versus $76 \pm 0.3$; summer $=$ $79 \pm 0.2$ versus $78 \pm 0.2$, respectively. THI values, calculated with the highest daily temperatures and the lowest daily humidity, as to simulate a midday situation, indicated moderate to high heat stress during most of the year.

The individual weight gain ( $\mathrm{kg} / \mathrm{animal} / \mathrm{day})$ did not vary significantly between the two systems (Fig. 5), but there was an interaction between system and season $(\mathrm{p}<0.05)$, reflecting the availability of pasture (Fig. 6). In the spring of 2014, the CPS permitted better individual performance than the SPS $(\mathrm{p}<$ $0.05)$.

Figure 6 depicts the variation in daily weight gain of the cattle raised in the two systems, per unit of area, according to season. The animals kept in the SPS had higher weight gains per area $(\mathrm{p}<0.05)$ throughout the experimental period. Although weight losses per area in the SPS were observed in October 2013 and JulySeptember 2014, they were not significantly different from the values observed among the CPS animals ( $p>0.05$ ). The animals in the CPS presented negative weight gains only in August 2014. The average stocking rates (Fig. 7) were similar between the two systems ( $p>0.05$ ), but the values observed in the SPS exceeded those in the CPS in summer 2013 (October and December, $\mathrm{p}<0.05$ ) and summer 2014 (December, $\mathrm{p}<0.05)$.

\section{Discussion}

In this experiment we studied the levels of infection by gastrointestinal nematodes in cattle raised in SPS and CPS, associating these with the climate data obtained in the two systems. We also calculated the individual weight gain, daily weight gain and pasture carrying capacity, to assess the result of these interactions on the animals' performance.

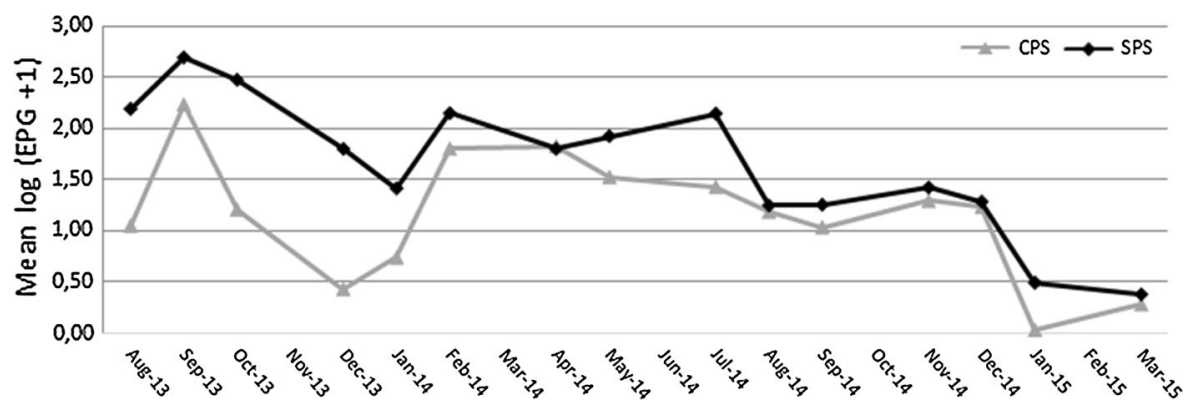

Fig. 3 Measures of the $\log (\mathrm{EPG}+1)$ per collection between August 2013 and March 2015, according to pasture system: CPS and SPS 
Fig. 4 Percentages of each parasite genus obtained from the coprocultures, according to collection month and pasture system: CPS and SPS
SPS
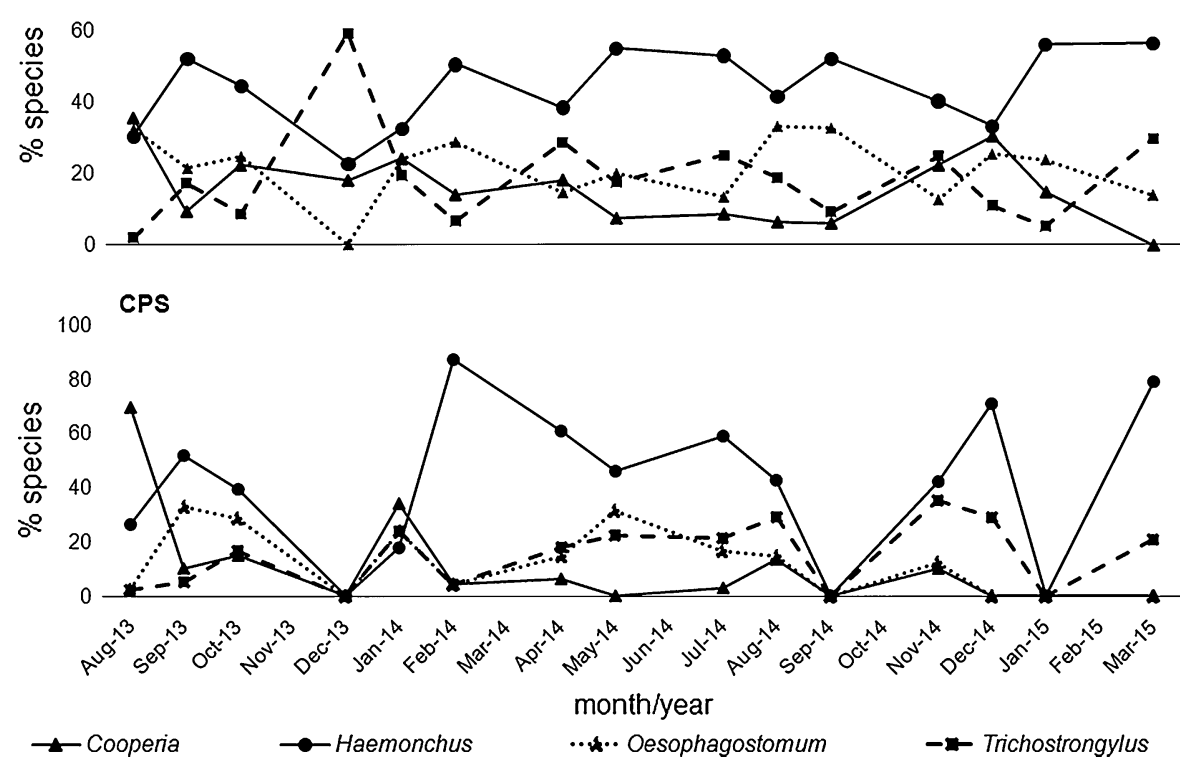

Fig. 5 Weight gain per animal, Canchim (5/8 Charolais/Zebu cross) steers, according to date, reared in a CPS and SPS

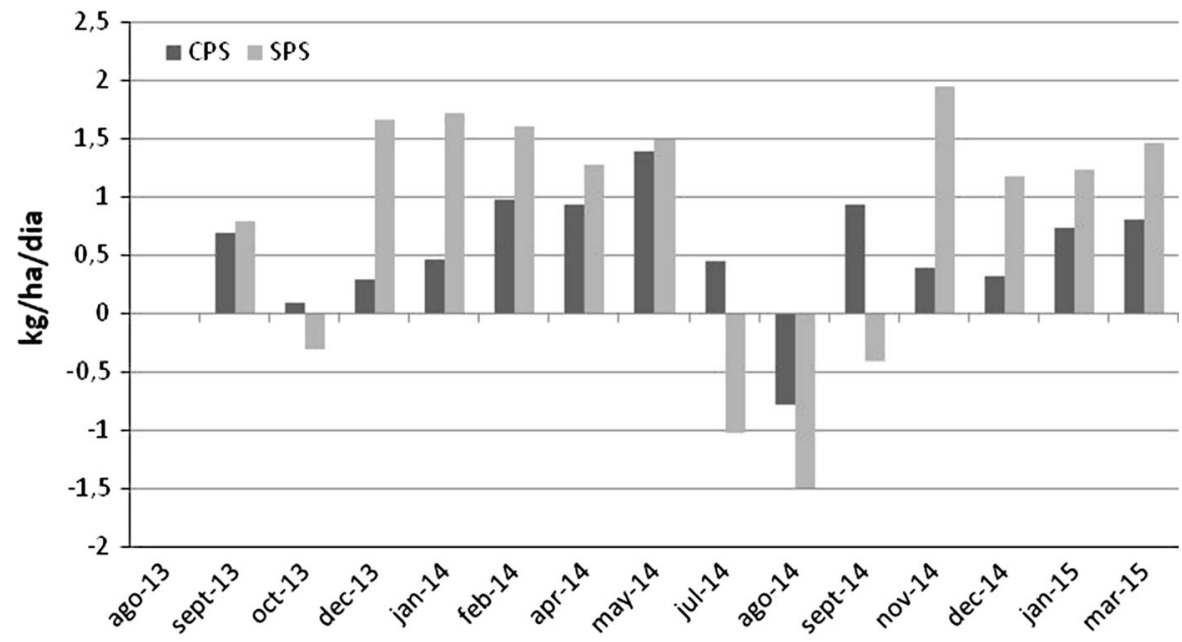

Evaluation dates
We found a significantly higher gastrointestinal nematode infection level in the cattle kept in the SPS. These findings differ from the results obtained in Cuba (Soca et al. 2007), where lower infection levels were observed in animals kept in pastures with trees. Those authors worked with young 5/8 Holstein (Bos taurus taurus) $x 3 / 8$ zebu (B. t. indicus) crossbred animals, in mixed pastures of grasses and legumes, and attributed the greater resistance to endoparasites to the ingestion of parts of the trees and legumes in the pastures. Two factors that affect the incidence of parasites-nutrition and biodiversity (Martinez and Merino 2011) —might have been favored by the SPS. Insufficient ingestion of proteins can aggravate infection by nematodes (Parkins and Holmes 1989), and the inclusion of legumes favors the supply of proteins. The diversification of diet achieved by Soca et al. (2007) might have brought significant gains due to the complementary supply of 
Fig. 6 Weight gain per area of Canchim (5/8 Charolais/ Zebu cross) steers and green dry matter offer, according to season and system type: CPS and SPS

Fig. 7 Stocking rate as AU/ ha according to date and system type: CPS and SPS
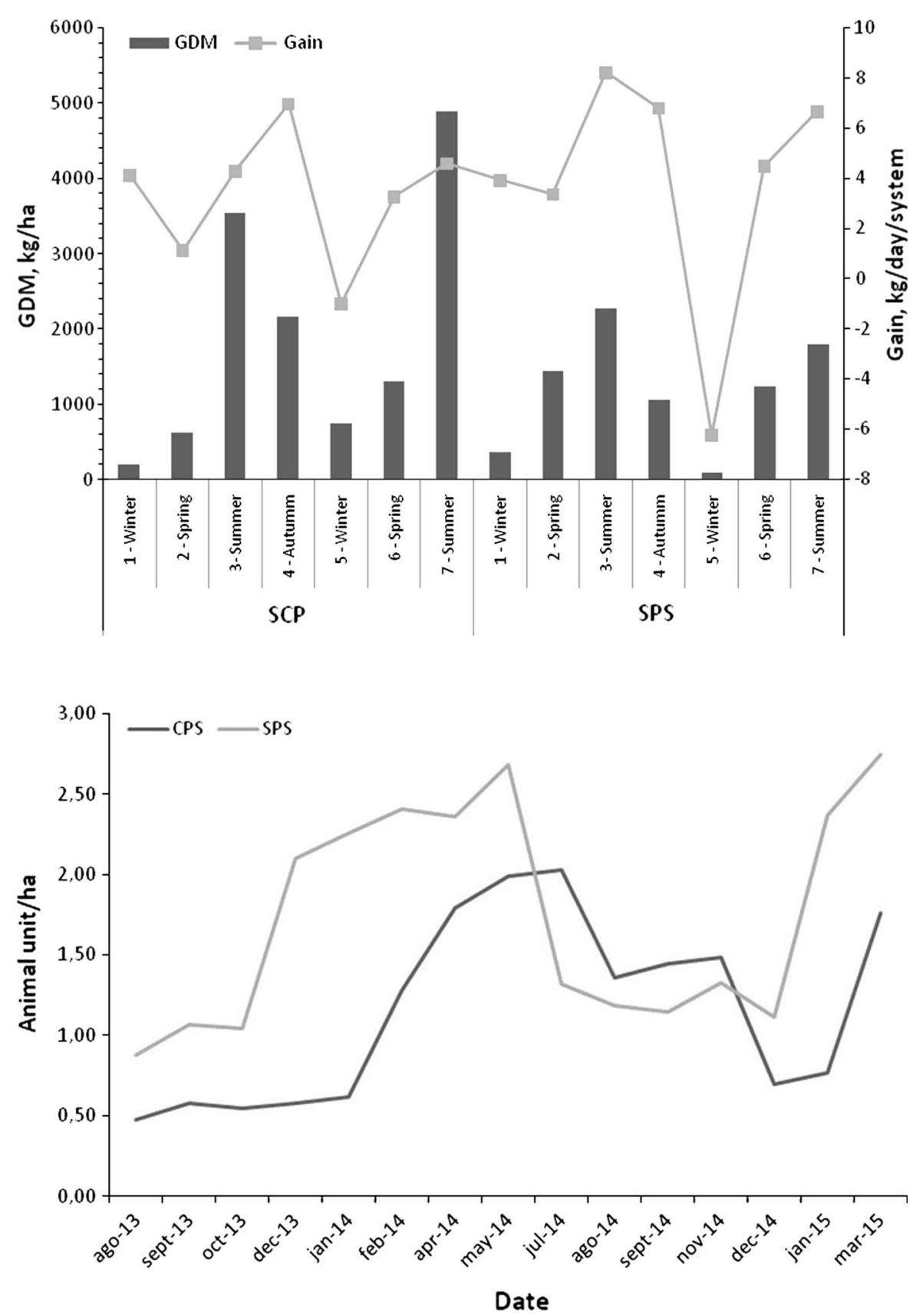

nutrients, greater balance between digestible and undegradable protein (Gutteridge and Shelton 1994) and better palatability and voluntary consumption, even reducing possible toxic effects of secondary metabolites, like tannins, present in some forages (Chen et al. 1991). Studies showed that the performance of sheep may be improved by the consumption of tannins, both for its ability to increase the availability of proteins in the small intestine of animals as for its deleterious effect on some stages of gastrointestinal nematodes (Niezen et al. 1993; Athanasiadou et al. 2000; Iqbal et al. 2007). Besides this, the greater biodiversity of silvopastoral in relation to conventional systems may have helped control parasitosis (Civitello et al. 2015). 
Our findings also differ from those of Mendonça et al. (2014) in the state of Minas Gerais (southeastern Brazil). They did not observe differences between the mean EPG values of crossbred Holstein and Gir animals (B. $t$. indicus) kept in a SPS formed mainly with Pterodon emarginatus, with density of 156 trees/ ha, associated with Brachiaria brizantha cv. Marandu, compared to conventional pasture, with 25 trees/ha. Besides the shorter period analyzed in that study (6 months), the greater tree density (600 trees/ha) in our study had a significant impact on the incident sunlight, which might have favored the development of nematodes.

Climate conditions have a decisive effect on the free-living phases of gastrointestinal nematodes that develop in pastures, since egg laying, hatching and development of the larvae as well as their ingestion by the definitive hosts all occur in this environment (Stromberg 1997). Temperature and soil moisture are considered the main factors that affect the development of the free-living stages of many Trichostrongylidae (Stromberg 1997; Lima 1998; Stromberg and Gasbarre 2006). However, according to O'Connor et al. (2006), after formation of the infective larva (L3), these factors become less important, since larvae at this stage are resistant to temperature and moisture conditions that would be lethal to larvae in the initial development stages. In this experiment, we monitored climate factors that might have influenced the parasites' survival in the pastures, and found significant differences between the systems for all the parameters evaluated (Table 1): solar radiation, wind speed, air and soil temperature. The microclimate in the pastures differed significantly between the two systems, with sunlight and wind speed differing the most, leading us to hypothesize that these favored the infection of the animals kept in the SPS. The attenuation of solar radiation by the trees in the SPS varied between 29 and $44 \%$ in the rainy season and from 19 to $51 \%$ in the dry season. The effect of sunlight on the survival of helminth larvae has been well characterized in controlled conditions. Hyun et al. (2008) observed an association between longevity and ability to repair damage to cell DNA induced by UV light in Caenorhabditis elegans. Van Dijk et al. (2009) investigated the direct effect of UV exposure on the mortality of infective nematode larvae in the laboratory and found mortality up to 2.27 greater in larvae exposed to high UV doses, showing that natural levels of this radiation increase the mortality of larvae in pastures. Besides the more intense sunlight, the stronger wind speed in the CPS also might have acted to reduce the soil moisture and survival of the recently hatched nematode larvae.

The region of the experiment has two distinct seasons: hot and humid summers and mild winters with sparse rainfall. In the period of this experiment, the lowest temperature observed was $5.6^{\circ} \mathrm{C}$ and the highest was $38.8^{\circ} \mathrm{C}$. Studies conducted in the southeast region of Brazil have shown that the prevailing temperatures enable the year-round development of free-living stages of nematode larvae in pastures, perhaps because the coldest periods are limited to only a few days (Lima 1998).

The soil moisture data showed that 2014 was particularly dry, with a significant water deficit in the summer (December 2013 through February 2014), and persistence of a dry climate until the end of spring (November 2014). Analysis of the moisture in the topmost soil layer $(0-10 \mathrm{~cm})$ of the pastures in the two systems did not reveal significant differences ( $p<0.05$ ), but the soil moisture might not have been the most important factor for the viability of the nematode larvae. Studies conducted in the same region have shown that infective larvae of these parasites remain viable and able to infect the host even in conditions of low moisture, perhaps because they remain in the dung pats or near them, managing to survive the desiccation and migrate more easily (Stromberg 1997; Lima 1998). Besides this, thirdstage larvae are particularly resistant to desiccation (Stromberg 1997). It is known that gastrointestinal parasites of ruminants, besides having strong resistance to adverse moisture conditions, can also benefit from anhydrobiosis, which increases the survival of Trichostrongylidae in pastures (Lettini and Sukhdeo 2006).

With respect to the nematode genera, Haemonchus, Cooperia, Oesophagostomum and Trichostrongylus were identified in the coprocultures during the entire experiment in both systems. The percentages of Haemonchus and Cooperia were significantly higher in the SPS. These parasites are prevalent in the mainly tropical stockbreeding conditions in Brazil (Nicolau et al. 2002; Araujo and Lima 2005; Bricarello et al. 2007; Oliveira et al. 2009, 2013). The genus Haemonchus also was found to be the principal parasite in the coprocultures of cattle raised in the SPS in Cuba 
mentioned earlier (Soca et al. 2007). This is expected, since this parasite finds hospitable transmission conditions at temperatures between 15 and $32{ }^{\circ} \mathrm{C}$ (Levine 1963). In contrast, Cooperia has strong ability to migrate in pastures, even under water deficit conditions (Lima 1998).

Various researchers studying cattle in Brazil have not found the occurrence of symptoms associated with moderate infections by gastrointestinal nematodes (Nicolau et al. 2002; Bricarello et al. 2007; Oliveira et al. 2009). We used grass paddocks, where the offer of dry green matter was mostly superior to $900 \mathrm{~kg} / \mathrm{ha}$, thus not limiting to cattle performance (Euclides and Euclides Filho 1998). In the winter when the quality of green mass declined, we provided protein enriched mineral supplement to the animals in both systems. This might have contributed to the absence of clinical signs of infection. We also did not find any associations between the PCV values, used to monitor health, and the levels of nematode infections. This indicator was within the normal range for bovines (Jain 1993) in all the animals.

For stockbreeders, the effect of parasite infections on livestock performance is fundamental. In this study, the individual weight gain, considering the entire experimental period, was similar between the two systems. Therefore, the higher level of infection by nematodes in the SPS did not have a negative effect on the cattle's performance. The stocking rate in the entire period, corrected for the pasture area available in each system, also was similar between the two systems. The use of these two variables together to calculate the weight gain per unit of area showed the advantage of using the SPS, but the need should be computed for roughage supplementation in the SPS, as occurred during the severe drought in 2014.

According to Müller (1989), the thermal comfort zone for cattle varies from 0.5 to $16{ }^{\circ} \mathrm{C}$ (taurine beef cattle) and from 15 to $26^{\circ} \mathrm{C}$ (zebu cattle). During the hottest times of day, the average air temperature exceeded the comfort zone of the cattle in the two systems. At midday the relative humidity reached its lowest level and the air temperature the highest level. In these conditions, the temperature and humidity index (THI) reached $76 \pm 0.2$ for CPS and $75 \pm 0.2$ fort SPS $(\mathrm{p}<0.05)$. Maximal THI values recorded reached 84 in CPS, considered critical for cattle. Provision of shade under the trees in the SPS is an important factor to reduce the effect of heat on the animals. The attenuation of solar radiation in the SPS varied between 29 and $44 \%$ during the hottest season, contributing to reduce the heat load.

The reduction of thermal stress might have contributed to the good result observed in the SPS. Conventional pastures in the Atlantic Forest biome contain an average of four to five trees per hectare (Andrade et al. 2012). With the planting of more trees in the pasture, the reduction in performance caused by heat stress (the result of a complex process of animal adaptation) can be minimized or avoided by the availability of shade under trees (Blackshaw and Blackshaw 1994). Heat stress affects not only consumption and metabolism of nutrients (Baumgard and Rhoads 2013). It also has an important impact on the immune response (Bernabucci et al. 2010), and consequently can have a negative effect on the host's resistance to parasites (Martinez and Merino 2011).

In conclusion, the presence of trees in the SPS affected the microclimate, reducing the sunlight incidence and wind speed compared to the CPS. These factors may have contributed to the greater presence of nematodes in the SPS, but this did not have a negative impact on the animals' weight gain and health. These results indicate that under the conditions studied, there is no need to alter the parasite management procedure to assure good productive performance of cattle.

Acknowledgment This project was supported by Fundação de Amparo à Pesquisa do Estado de São Paulo (FAPESP/201205858-0) and Empresa Brasileira de Pesquisa Agropecuária (EMBRAPA/CPPSE).

\section{References}

Aguilar J, Rumiatto MA, Kruker JM,da Silva CA, de Calheiros RO (1986) Sistema de programas, em linguagem basic, para cálculo da evapotranspiração potencial por meio de métodos indiretos e do balanço hídrico-climático. EMBRAPA-UEPAE Dourados, Dourados. http://ainfo. cnptia.embrapa.br/digital/bitstream/item/65885/1/CPAODOC.-23-86.pdf. Accessed 25 Sept 2015

Andrade CMS, Salman AKD, Oliveira TK (2012) Guia arbopasto: manual de identificação e seleção de espécies arbóreas para sistemas silvipastoris. Embrapa, Brasília

Araujo RN, Lima WS (2005) Infecções helmínticas em um rebanho leiteiro na região do Campo das Vertentes de Minas Gerais. Arq Bras Med Vet Zootec 57(2):186-193

Athanasiadou S, Kyriazakis I, Jackson F, Coop RL (2000) Effects of short-term exposure to condensed tannins on 
adult Trichostrongylus colubriformis. Vet Rec 146:728-732

Baumgard LH, Rhoads RP Jr (2013) Effects of heat stress on post absorptive metabolism and energetics. Annu Rev Anim Biosci 1:311-337

Bernabucci U, Lacetera N, Baumgard LH, Rhoads RP, Ronchi B, Nardone A (2010) Metabolic and hormonal acclimation to heat stress in domesticated ruminants. Animal 4:1167-1183

Blackshaw JK, Blackshaw AW (1994) Heat stress in cattle and the effect of shade on production and behaviour: a review. Aust J Exp Agric 34:285-295

Bricarello PA, Zaros KG, Coutinho LL, Rocha RA, Kooyman E, De Vries E, Gonçalves JRS, Lima LG, Pires AV, Amarante AFT (2007) Field study on nematode resistance in Nelorebreed cattle. Vet Parasitol 148:272-278

Chen CP, Halim RA, Chin FY (1991) Fodder trees and fodder shrubs in range and farming systems of the Asian and Pacific region. In: Speedy A, Pugliese PL (eds) Legume trees and other fodder trees as protein sources for livestock. FAO expert consultation, Kuala Lumpur. http://www.fao. org/DOCREP/003/T0632E/T0632E02.HTM\#CH2

Civitello DJ, Cohen J, Fatima H, Halstead NT, Liriano J, McMahon TA, Orteg CN, Sauer EL, Sehgal T, Young S, Rohr JR (2015) Biodiversity inhibits parasites: broad evidence for the dilution effect. Proc Natl Acad Sci USA 112:8667-8671

Corwin RM (1997) Economics of gastrointestinal parasitism of cattle. Vet Parasitol 72:451-460

Di Rienzo JA, Casanoves F, Balzarini MG, Gonzalez L, Tablada M, Robledo CW (2011) InfoStat Grupo InfoStat, FCA. Universidad Nacional de Córdoba, Argentina. http://www. infostat.com.ar

EMBRAPA-Empresa Brasileira de Pesquisa Agropecuária, Centro Nacional de Pesquisas de Solos- CNPS (2006) Sistema brasileiro de classificação de Solos, 2nd edn. EMBRAPA Solos, Rio de Janeiro

Euclides VPB, Euclides Filho K (1998) Uso de animais na avaliação de forrageiras. Embrapa-CNPGC, Campo Grande (Embrapa-CNPGC. Documentos, 74). http://www. infoteca.cnptia.embrapa.br/infoteca/handle/doc/318251

Garcia R, Couto L (1991) Silvopastoral systems: experiências no estado de Minas Gerais. Congresso Brasileiro de Economia e planejamento Florestal 2:102-106

Gutteridge RC, Shelton HM (eds) (1994) Forage tree legumes in tropical agriculture. CAB International, Wallingford, p 389

Hyun M, Lee J, Lee K, May A, Bohr VA, Ahn B (2008) Longevity and resistance to stress correlate with DNA repair capacity in Caenorhabditis elegans. Nucleic Acids Res 36(4):1380-1389

IBGE Instituto Brasileiro de Geografia e Estatística (2006) Censo agropecuário 2006. Brasil. http://www.ibge.gov.br/ home/estatistica/economia/agropecuaria/censoagro/brasil_ 2006/Brasil_censoagro2006.pdf

Iqbal Z, Sarwar M, Jabbar A, Ahmed S, Nisa M, Sajid MS, Khan MN, Mufti KA, Yaseen M (2007) Direct and indirect anthelmintic effects of condensed tannins in sheep. Vet Parasitol 144:125-131

Jain NC (1993) Essentials of veterinary hematology. Lea \& Febiger, Philadelphia

Lettini SE, Sukhdeo MVK (2006) Anhydrobiosis increases survival of trichostrongyle nematodes. J Parasitol 92(5):1002-1009
Levine ND (1963) Weather climatic and the biomics of ruminant nematode larvae. Adv Vet Sci 8:215-261

Lima WS (1998) Seasonal infection pattern of gastrointestinal nematodes of beef cattle in Minas Gerais state, Brazil. Vet Parasitol 74:203-214

Martinez J, Merino S (2011) Host-parasite interactions under extreme climatic conditions. Curr Zool 57:390-405

Mendonça RMA, Leite RC, Lana AMQ, Costa JO, Toth G (2014) Parasitic helminth infection in young cattle raised on silvopasture and open-pasture in southeastern Brazil. Agrofor Syst 88:53-62

Müller PB (1989) Bioclimatologia aplicada aos animais domésticos. Sulina, Porto Alegre

Nicolau CVJ, Amarante AFT, Rocha GP, Godoy WAC (2002) Relação entre desempenho e infecções por nematódeos gastrointestinais em bovinos Nelore em crescimento. Arq Bras Med Vet Zootec 54(4):351-357

Niezen JH, Waghorn TS, Waghorn GC, Charleston WAG (1993) Internal parasites and lamb production: a role for plants containing condensed tannins? Proc NZ Soc Anim Prod 53:235-238

O'Connor LJ, Walkden-Brown S, Kahn LP (2006) Ecology of the free-living stages of major trichostrongylid parasites of sheep. Vet Parasitol 142:1-15

Oliveira MCS, Alencar MM, Chagas ACS, Giglioti R, Oliveira HN (2009) Gastrointestinal nematode infection in beef cattle of different genetic groups in Brazil. Vet Parasitol 166:249-254

Oliveira MCS, Alencar MM, Giglioti R, Beraldo MCD, Aníbal FF, Correia RO, Boschini L, Chagas ACS, Bilhassi TB, Oliveira HN (2013) Resistance of beef cattle of two genetic groups to ectoparasites and gastrointestinal nematodes in the state of São Paulo, Brazil. Vet Parasitol 197:168-175

Parkins JJ, Holmes PH (1989) Effects of gastrointestinal helminth parasites on ruminant nutrition. Nutr Res Rev 2:227-246

Roberts IH, O'Sullivan PJ (1950) Methods for egg counts and larval cultures for strongyles infesting the gastrointestinal tract of cattle. Aus J Agric Res 1:99-102

Schlesinger S (2010) Onde pastar?. O gado bovino no Brasil, Fase

Soca M, Simón L, Roque E (2007) Trees and gastrointestinal nematodes in young cattle: a new research approach. Pastos y Forrajes 30:21-32

Souza W, Barbosa OR, Marques JA, Gaparino E, Cecato U, Barbero LM (2010) Behavior of beef cattle in silvopastoral systems with eucalyptus. Rev Bras Zootec 39(3):677-684

Statistical Analysis System (2002/2003) SAS. SAS/STAT. User's Guide, version 9.1.3

Stromberg B (1997) Environmental factors influencing transmission. Vet Parasitol 72:247-264

Stromberg BE, Gasbarre LC (2006) Gastrointestinal nematode control programs with an emphasis on cattle. Vet Clin Food Anim 22:543-565

Stromberg B, Gasbarre LC, Waite A, Bechtol D, Brown MS, Robinson NA, Olson EJ, Newcomb H (2012) Cooperia punctata: effect on cattle productivity? Vet Parasitol 183:284-291

Takahashi LS, Biller JD, Takahashi KM (2009) Bioclimatologia Zootécnica. Unesp, Jaboticabal. https://bioclimatologia. files.wordpress.com/2012/08/livro-bioclimatologia-zootc3a9 cnica.pdf 
Thornthwaite CW, Mather JR (1955) The water balance. Publications in climatology, vol 8 No. 1. C.W. Thornthwaite Associates, Elmer

Ueno H, Gonçalves PC (1998) Manual para Diagnóstico das Helmintoses dos ruminantes. Jica, Tokyo
Van Dijk J, De Louw MDE, Kalis LPA, Morgan ER (2009) Ultraviolet light increases mortality of nematode larvae and can explain patterns of larval availability at pasture. Int J Parasitol 39:1151-1156 